\title{
Speeds and stance of titanosaur sauropods: analysis of Titanopodus tracks from the Late Cretaceous of Mendoza, Argentina
}

\author{
BERNARDO J. GONZÁLEZ RIGA \\ Departamento de Paleontología, IANIGLA, CCT-CONICET-Mendoza, Avda. Ruiz Leal s/n, Parque Gral. San Martín \\ (5500) Mendoza, Argentina/Instituto de Ciencias Básicas, Universidad Nacional de Cuyo \\ Manuscript received on November 13, 2009; accepted for publication on June 21, 2010
}

\begin{abstract}
Speed estimations from trackways of Titanopodus mendozensis González Riga and Calvo provide information about the locomotion of titanosaurian sauropods that lived in South America during the Late Cretaceous. Titanopodus ichnites were found at Agua del Choique, a newly discovered track site in the Loncoche Formation, Late Campanian-Early Maastrichtian of Mendoza, Argentina. This speed study follows the hypothesis of dynamic similarity proposed by Alexander. As a refinement of this method, a complementary equation is presented here based on an articulated titanosaurian specimen collected in strata that are regarded as correlative to those that have yielded Titanopodus tracks (Allen Formation, Neuquén Basin). This analysis indicates that hip height can be estimated as 4.586 times the length of the pes track in derived titanosaurs. With an estimation of the hip height and the stride measurements, the speed is calculated. The study of two wide-gauge trackways indicates that Titanopodus ichnites were produced by mediumsized titanosaurs (hip height of 211-229 cm) that walked at 4.7-4.9 km/h towards the south and southwest, following, in part, a sinuous pathway. These speeds and some taphonomic features of tracks (prominent rims, distorted elongated shapes) indicate the capacity of derived titanosaurs for walking effectively over a very wet and slippery substrate. In the ichnological record, the walking speeds of Titanopodus trackmakers are somewhat faster than those previously inferred for most sauropods.
\end{abstract}

Key words: speed, Sauropoda, Titanopodus, Cretaceous, Argentina.

\section{INTRODUCTION}

Important dinosaur tracksites have been described in South America, particularly in Chile (Casamiquela and Fasola 1968, Moreno and Pino 2002, Moreno et al. 2004, Moreno and Benton 2005), Bolivia, and Brazil (Leonardi 1989, Meyer et al. 2001, Lockley et al. 2002). In Argentina, dinosaur track sites are known from Salta, Neuquén, and Mendoza provinces.

In Salta (near eastern Puna), theropod and ornithopod tracks were discovered in the upper levels of the Yacoraite Formation (Maastrichtian) (Alonso 1980, Alonso and Marquillas 1986). In this province, sauropod footprints have not been described yet.

Proceedings of the Third Gondwanan Dinosaur Symposium E-mail: bgonriga@yahoo.com.ar
In Neuquén (northern Patagonia), dinosaur tracks have been found in the Picún Leufú and El Chocón areas (Fig. 1). These tracks were found in outcrops of the Candeleros Formation (Cenomanian), a unit that is characterized by deposits corresponding to meandering rivers, poorly channeled ephemeral flows, and playa lakes. Titanosaurian tracks from this formation were named Sauropodichnus giganteus (Calvo 1991, 1999).

Recently, a new tracksite, the first to be described from Mendoza Province, was discovered in the Late Campanian-Early Maastrichtian strata of the Loncoche Formation (González Riga and Calvo 2007, 2009). Around 300 sauropod footprints and some small theropod tracks were identified at this track site. The sauro- 
pod tracks were recently assigned to a new ichnotaxon named Titanopodus mendozensis (González Riga and Calvo 2009). These tracks are an excellent example of the wide-gauge style of sauropod locomotion without impressions of manual phalanges. These features, together with the fossil record of the Loncoche Formation and equivalent units in Patagonia (Allen and Los Alamitos Formations), suggest that the Titanopodus trackmakers were, probably, saltasaurine or aeolosaurine titanosaurs.

Titanosauria is a diverse sauropod clade that includes more than 50 species of worldwide distribution. However, studies of speed, gait and stance of these dinosaurs are scarce and most biomechanical aspects related to titanosaur locomotion are unknown. Only Sauropodichnus tracks, which have been attributed to basal titanosaurs, have been studied in this regard (Mazzetta and Blanco 2001, Calvo and Mazzeta 2004). In this context, the objective of this paper is to study, for the first time, the speeds and stance of the Titanopodus trackmakers. This study is important for understanding the locomotion and behavior of the latest titanosaurs that lived during the Late Cretaceous.

\section{MATERIALS AND METHODS}

This paper is based on a dinosaur track site located at Agua del Choique, $14 \mathrm{~km}$ west of the city of Malargüe in Mendoza Province, Argentina (Fig. 1A). At this paleoichnological outcrop, the author and his team discovered multiple track-bearing levels both in the Anacleto and Loncoche Formations.

In the upper section of the Anacleto Formation (Early Campanian), three levels with sauropod tracks were located in floodplain fluvial facies (Fig. 1B).

In the middle section of the Loncoche Formation (Late Campanian-Early Maastrichtian), two different levels with dinosaur tracks were found (Fig. 1B). One of them occurs in a yellow grey calcareous sandstone and pertains to Titanopodus mendozensis (González Riga and Calvo 2009). The other track level is located $80 \mathrm{~cm}$ above the former and is exposed only in crosssection.

The Loncoche Formation is the lower unit of the Malargüe Group and unconformably overlies the Anacleto Formation. At different sites in Mendoza
Province, this Formation is comprised by marginal marine facies (e.g., tidal flats, deltas, sabkhas deposits) that were produced by a shallow transgression of the Atlantic Ocean that covered central-northern Patagonia (González Riga and Parras 1998). In the Ranquil-Có and Calmu-Co sections, the Loncoche Formation has yielded a varied association of fossil fishes and reptiles (González Riga 1999, Previtera and González Riga 2008). These vertebrate assemblages are associated with ancient tidally dominated deltaic deposits and include a mixture of terrestrial vertebrates (dinosaurs and snakes), together with freshwater taxa (e.g. turtles, fishes), as well as marine or littoral forms (plesiosaurs and rays).

Parras et al. (1998) recognized two depositional environments in the Agua del Choique area. The first is attributed to a river-dominated delta and lake setting, and the second corresponds to a river-dominated delta that changed to a tide-dominated delta. A detailed environmental analysis of the Titanopodus track site, including sedimentological and paleopalynological data, is presently in progress and will be published elsewhere.

The Titanopodus level dips 12 degrees towards the northeast $\left(80^{\circ}\right)$. It extends across three areas. Area A $\left(35^{\circ} 26^{\prime} 55.2 \mathrm{~S} ; 69^{\circ} 44^{\prime} 2.0^{\prime \prime} \mathrm{W}\right)$ includes approximately 160 tracks in four principal trackways (AC-1 to AC-4 in this paper). Area $B$ is located $234 \mathrm{~m}$ to the south of area $A$ and comprises around 100 tracks partially covered by sediments. Area $\mathrm{C}$ is located $150 \mathrm{~m}$ south of area $\mathrm{B}$ and includes more than 50 tracks (González Riga and Calvo 2009). In this paper we analyze trackways from area $A$.

The trackways were photographed and mapped, and some tracks were cast with plaster under the abbreviation of IANIGLA-PV.

The first method for estimating the speed of dinosaurs was proposed by Alexander (1976), who supported his analysis using the hypothesis of dynamic similarity. According to this hypothesis, the movements of animals with geometrically similar shapes, even if they are different in size, are dynamically similar only when they move with equal values of the Froude number. This number is a non-dimensional parameter used where inertia and viscous forces interact. This parameter is defined in terrestrial locomotion as $V^{2} / G H$, where $V$ is the speed, $G$ is the acceleration of free fall, and $H$ is the height of the hip joint from the ground. 

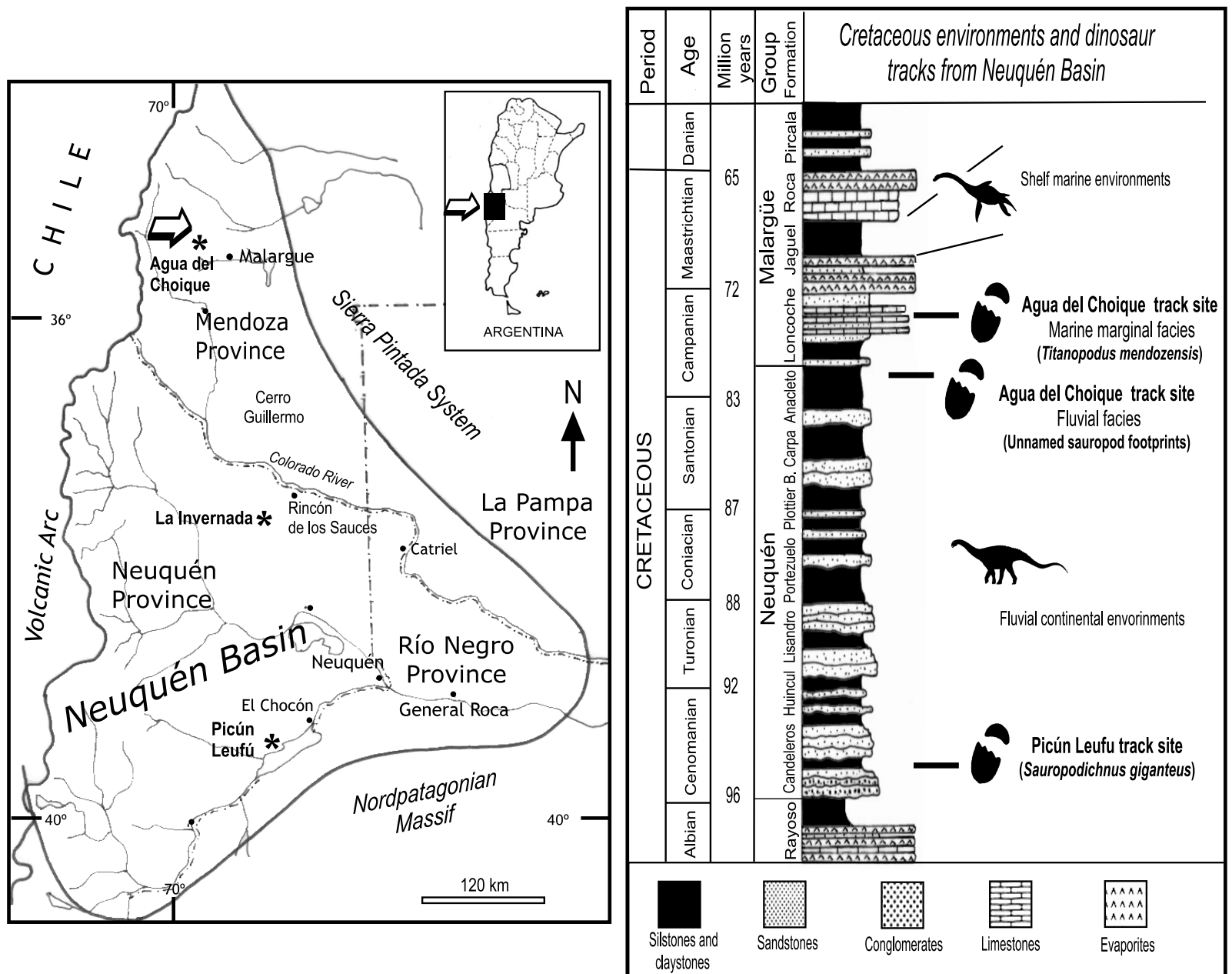

Fig. 1 - A, Location of the Neuquén Basin (Argentina) showing the Agua del Choique and Picún Leufú tracksites (after González Riga and Calvo 2009); B, Stratigraphic column of the Neuquén Basin showing track levels (modified from González Riga 2002).

Dynamically similar movements (i.e., those with equal Froude numbers) require equal values of relative stride length ( $S / H$ where $S$ is stride length). The relationship between the relative stride length and the Froude number allows one to estimate speed. On this basis, Alexander (1976) proposed the following equation:

$$
V=0.25 G^{0.5} S^{1.67} H^{-1.17}
$$

In this formula, the $S$ and $H$ values are entered in meters and $V$ is solved in meters per second. Although refinements to the method have been proposed in attempts to make it more accurate (see critical review of Alexander 2006), at present this approach remains the best method for estimating the speeds of dinosaurs via their tracks.
This method involves the measurement of stride length $(S)$ and the estimation of height at the hip $(H)$. The parameter $S$ is the distance among corresponding points on successive prints of the same foot, and is easily measured in trackways. In contrast, the estimation of $H$ is difficult because it is related with the length of the hind foot print $(L)$ through some mathematical ratios. This parameter is tested for derived titanosaurs in this paper.

Alexander (1976) has pointed out that extant terrestrial mammals change from a walk to a run or trot when the ratio of stride length to hip height $(S / H)$ reaches a value of about 2.0, and suggests that the same was probably true for dinosaurs. In subsequent studies of dinosaur locomotion (Thulborn 1982, Thulborn 
and Wade 1984), Alexander's (1976) observations on the gaits of extant vertebrates were extended to define three different gaits in dinosaurs: walk $(S / H<2.0)$, trot $(S / H$ between 2.0 and 2.9), and run $(S / H>2.9)$.

Finally, the equation (1) is limited to estimating the speed at which a particular trackway was made and cannot be used for estimating the top running speed of a dinosaur (Coombs 1978).

\section{InSTITUTIONAL ABBREVIATIONS}

IANIGLA-PV - Instituto Argentino de Nivología, Glaciología y Ciencias Ambientales, Colección Paleovertebrados, Argentina.

MUCPv - Museo de Geología y Paleontología, Universidad Nacional del Comahue, Argentina.

\section{RESULTS AND DISCUSSIONS}

\section{ANALysis of ANATOMicAl Evidences}

An estimation of the height at the hip joint $(H)$ is the first step for calculating the speed of a given dinosaur. Alexander (1976), following the skeletal proportions of the diplodocid sauropod Apatosaurus, considered that $H$ is four times the length of the pes footprint $(L)$. He estimated similar values (e.g., $L=0.23-0.38 H$ ) for many bipedal dinosaurs of a wide range of sizes, both theropods and ornithopods.

Thulborn (1990) claimed that the assumption of $H=4 L$ is likely to be incorrect for two reasons. First, the $H / L$ ratio varies in systematic fashion among dinosaur taxa. Second, the $H / L$ ratio certainly changes during ontogeny, on account of the allometric growth that prevails in terrestrial vertebrates. This author supposed that juveniles have relatively larger feet (and therefore smaller $H / L$ ratio) than do adults of the same taxon.

In bipedal dinosaurs, Alexander (1991) and Thulborn and Wade (1984) proposed some refinements to this estimation using allometric equations in some cases. Alternatively, Henderson (2003) studied other methods using computer models. In contrast, recommendations for quadrupedal dinosaurs are less clear because, in many groups like sauropods, the pes has a large padded area. For sauropods, Thulborn (1990) has suggested that $H=$ 5.9L, while Lockley (1986) used $H=4 W$ where $W$ is the foot width.
In this paper, as refinements of previous studies, I estimate the hip height of derived titanosaurs using anatomical and ichnological lines of evidence.

First, it is important to analyze the anatomical proportions of the probable trackmakers. The ichnological features of Titanopodus indicated that its trackmakers were sauropods of wide-gauge stance where both manus and pes prints were well separated from the midline, as is described in titanosauriforms (Wilson and Carrano 1999). In trackway AC-1 (Fig. 2, holotype of Titanopo$d u s$ ), the total width of the trackway is about 125-132 $\mathrm{cm}$, and the inner trackways width is about $40 \mathrm{~cm}$. This feature can be carefully analyzed following the manus and pes trackway ratios (MTR and PTR) proposed by Romano et al. (2007). These indices are defined as the ratio of the track width measured transversely to the midline (side width, $S W$ ) relative to the total width of the trackway (overall width, $O W$ ) as follows: $T R=$ $S W / O W \times 100$. In the present case, trackway AC-1 shows MTR and PTR values of 22.09 and 31.32 per cent, respectively. These values indicate that Titanopo$d u s$ has a very wide-gauge trackway in comparison with other known trackways. Moreover, the absence of impressions of manual phalanges and the Late Cretaceous age of these ichnites indicate that the trackmakers were, probably, derived titanosaurs.

In Argentina, almost all Late Campanian-Maastrichtian sauropods correspond to Aeolosaurini and Saltasaurinae titanosaurs. The aeolosaurines include Aeolosaurus rionegrinus from the Angostura Colorada Formation (Powell 1987). The named species of saltasaurines comprise two forms from the Allen Formation: Bonatitan reigi (Martinelli and Forasiepi 2004) and Rocasaurus muniozi (Salgado and Azpilicueta 2000), and one species from the Lecho Formation: Saltasaurus loricatus (Bonaparte and Powell 1980).

It is important to consider that, in the same strata that have yielded Titanopodus tracks (precisely the Allen Formation, a lateral equivalent of the Loncoche Formation and also deposited in the Neuquén Basin), two saltasaurine titanosaurs have been found: Bonatitan and Rocasaurus. A third taxon, a derived and unnamed taxon closed to saltasaurines, was discovered in La Invernada quarry (González Riga et al. 2008). 

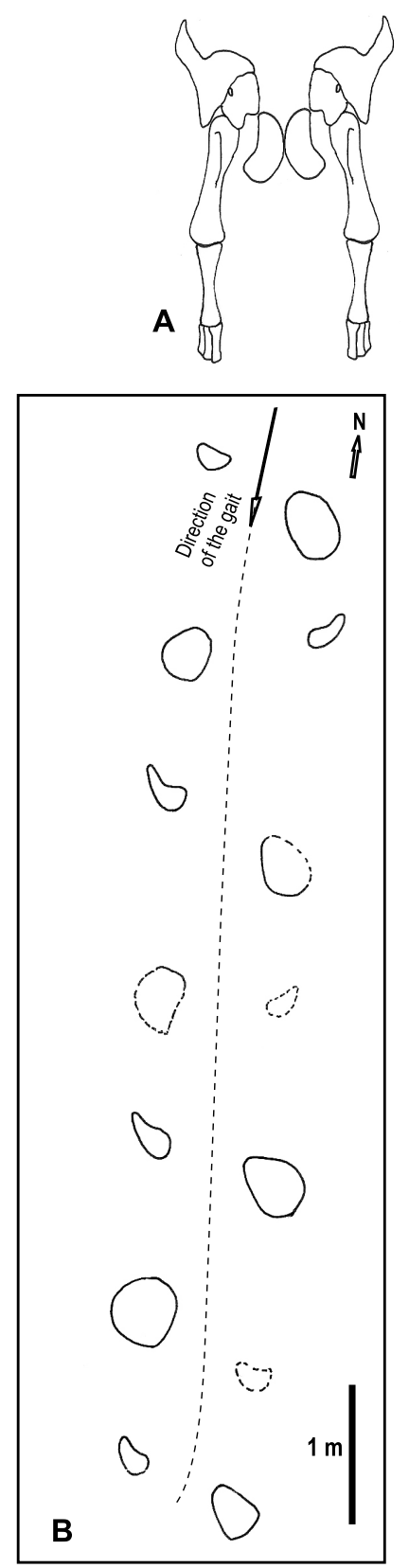

Fig. 2 - A, Schematic pectoral girdle and forelimbs of a derived titanosaur (modified from Borsuk-Bialynicka 1977). B, Titanopodus mendozensis, map of trackway AC-1 (after González Riga and Calvo 2009).

Obviously, we cannot definitively identify the trackmaker of Titanopodus to the genus level; however, it is reasonable to analyze the proportions of the best preserved of these derived titanosaurs to estimate the $H / L$ ratio and to obtain a more accurate value of $H$.
Among these titanosaurs, an interesting specimen for studying the appendicular skeleton is that of the La Invernada taxon (MUCPv-1533). It was discovered $230 \mathrm{~km}$ south of the Titanopodus tracksite and preserves the caudal series and fore- and hind limbs, the latter including a complete and articulated left pes (González Riga et al. 2007, 2008).

The forelimb of MUCPv-1533 includes five articulated metacarpals, which form a semi-tubular and U-shaped vertical structure, as in other sauropods (Upchurch 1994, Wilson and Sereno 1998, Wilson 2002). This particular morphology limited tensional stress in the forearm, and was related to the gigantism of these quadrupedal dinosaurs (Bonnan 2003). This specimen preserves no evidence of manual phalanges, as in almost all derived titanosaurs (Salgado et al. 1997, Calvo et al. 2007). A partially similar condition is observed in Epachthosaurus from the Late Cenomanian-Early Turonian of Chubut Province, Argentine Patagonia (Martínez et al. 2004), and Opisthocoelicaudia from the Maastrichtian of Mongolia (Borsuk-Bialynicka 1977). In these two species, no manual phalanges are present, with the exception of a vestigial element fused to the distal surface of metacarpal IV.

In the ichnological record, the semi-tubular structure of the sauropod metacarpus is preserved, in most cases, as a characteristic crescent shape of manus track (e.g., Farlow et al. 1989, Lockley 1991, Santos et al. 1994, Calvo 1999, Lockley et al. 2004, Wright 2006). In particular, the manus tracks of Titanopodus shows a strongly asymmetrical crescentic contour and exhibit, no evidence of manual phalanges (Fig. 3B-C). This asymmetry is in agreement with the manus of the specimen MUCPv-1533, where the metacarpals I and II are very robust elements in comparison with more laterally-positioned metacarpals (Fig. 3D). This asymmetry is absent in the Patagonian titanosaur Epachthosaurus (Fig. 3E), since the metacarpals III and IV are almost as robust as the medial-positioned metacarpals (Martínez et al. 2004). In contrast, in Rapetosaurus krausei from the Maastrichtian of Madagascar, a very different case is observed: the metacarpal $\mathrm{V}$ is the most robust of all metacarpals (Curry Rogers and Foster 2001, Curry Rogers 2009). 

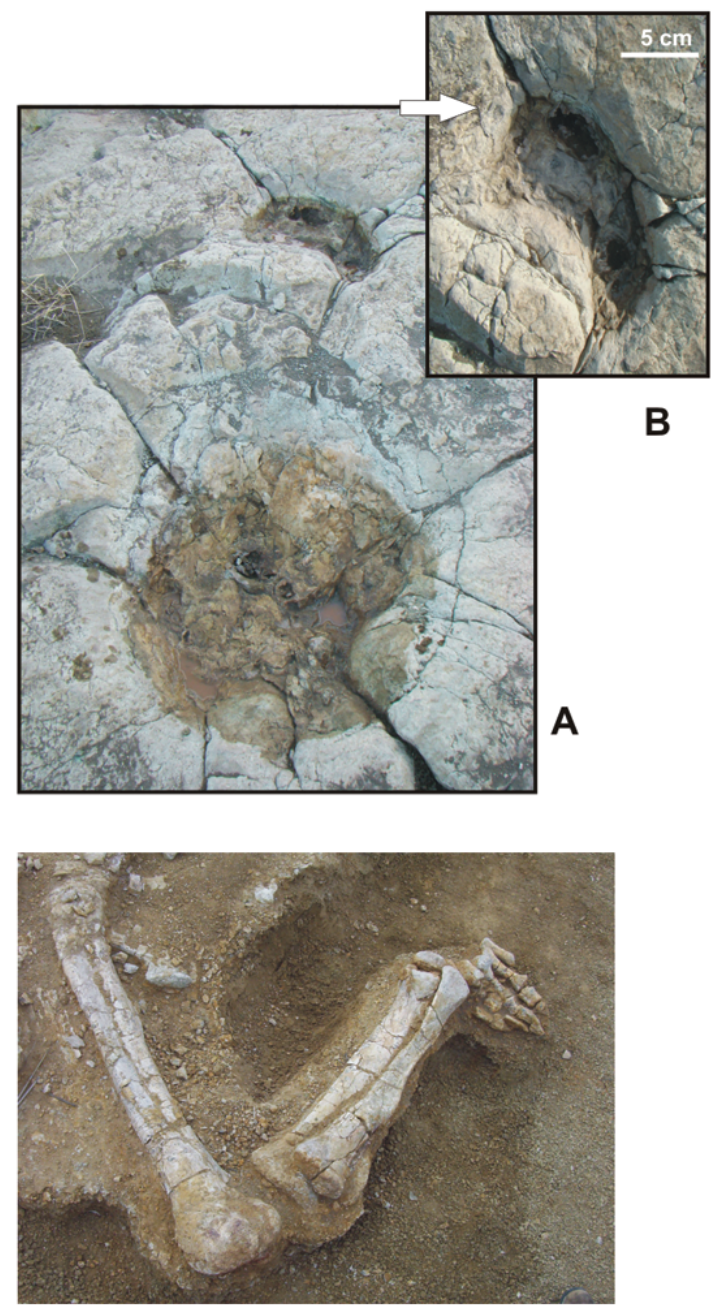

$\mathbf{F}$
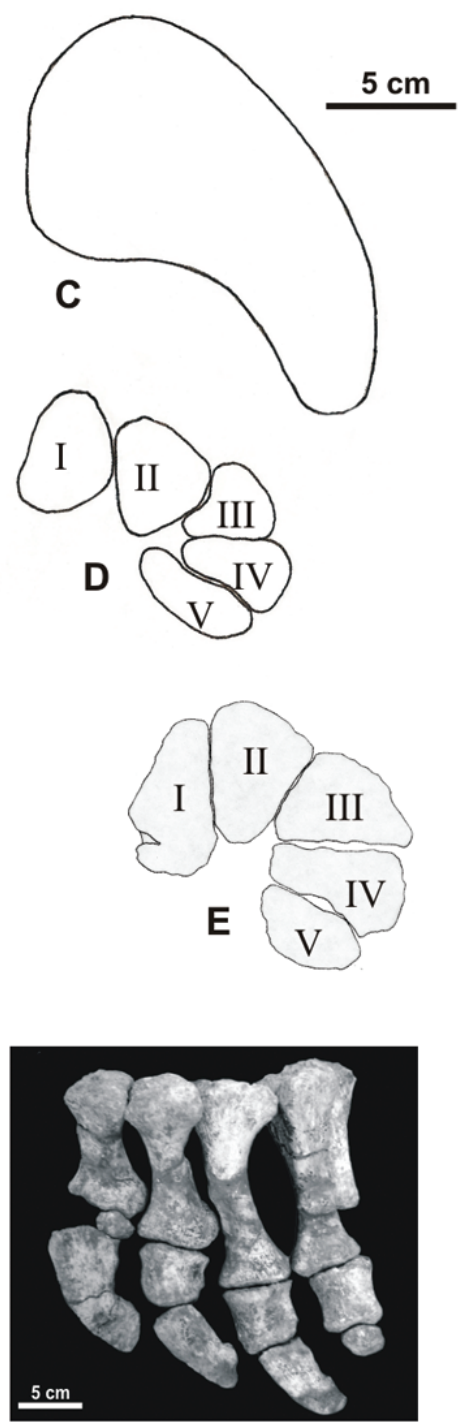

G

Fig. 3 - A-C, Titanopodus mendozensis tracks from Mendoza Province, Argentina: A, field photographs of a manus-pes track set and a left manus (B); C, left manus track of T. mendozensis in comparison with the articulated left metacarpus in dorsal views of the titanosaur MUCPv-1533 (D) and Epachthosaurus (E). F-G, Titanosaur MUCPv-1533 from La Invernada, Neuquén Province, Argentina: F, articulated left hind limb, G, complete left pes in dorsal view (E, after Martinez et al. 2004, and F-G after González Riga et al. 2008).

The pes of MUCPv-1533 is also typically asymmetrical, relatively short and wide (Fig. 3F). Metatarsals III and IV are the longest elements; the phalangeal formula is: $2-2-2-2-0$, and the first three digits carry sickle-shaped unguals (González Riga et al. 2008). The asymmetry of the South American titanosaur pedes is related with a progressive reduction in the size and number of pedal phalanges in digits III and IV towards the end of the Cretaceous (González Riga et al. 2008).
Recently, several aspects of sauropod pedes have been explained as a hypermorphism process, following a morphodynamic approach (Lockey 2007, Lockley and Jackson 2008).

In a preliminary reconstruction of the hind limb, I assume a semi-plantigrade posture, with an angle of inclination (measured with respect to the horizontal plane) of $50^{\circ}$ for metatarsal III, following the in situ arrangement of the La Invernada titanosaur. Bonnan 
(2005) proposed a similar disposition $\left(45^{\circ}\right)$ for sauropods in general, following the hypothesis that these dinosaurs had an elastic plantar pad. There are no detailed studies of these postural aspects in titanosaurs, but it is possible that, within a single pes, different metatarsals had differing inclinations, as in modern elephants. In these mammals, the digitigrade pedes are functionally plantigrade (Miller et al. 2007) due to the presence of a fatty foot pad that acts in a fashion analogous to highheeled shoes in humans.

In the graphic reconstruction of the specimen MUCPv-1533 (Fig. 4), the acetabulum (e.g., the hip joint) is located $197 \mathrm{~cm}$ above the ground.

\section{Estimation of Hip Joint Height}

Based on the reconstruction of the titanosaur hind limb (Fig. 4), the hip joint height can be expressed as an equation:

$$
H=F-A f+K e+T+A+M t \cdot \cos \alpha+P h p
$$

In this equation, $F$ is the femur length, $A f$ is the distance between the proximal end of the femur and the horizontal axis of movement of the femoral head $(\sim 7 \%$ of the femur length), $\mathrm{Ke}$ (Knee) is the space for the femoral-tibial articulation (preliminarily, I assumed a value of $\sim 3 \%$ of the femur length), $T$ is the tibia length, $A$ is the height of the astragalus, $M t$ is the length of the metatarsal III, a is the inclination of the metatarsals (usually interpreted as $40-50^{\circ}$ ), and $P h p$ is the height of a hypothetical pad located ventral to the phalanges, following Gallup's (1989) reconstruction of the pes of the titanosauriform Pleurocoelus. In this formula, I assume that $P h p$ is $50 \%$ of the dorsoventral diameter of the first phalanx of digit III (see Php in Fig. 4).

Also included in this reconstruction is an elastic plantar pad (as a heel) that distributes the weight transmitted through the pes. Obviously, the development of this plantar pad can modify the reconstruction of the length of the pes track. I assume that the track length $(L)$ can vary by about $5 \%$ depending on different interpretations of this plantar pad $(P L)$. Other feature is the lateral orientation of the ungual phalanges $(U)$, which is present in most sauropods. In the graphic reconstruction, it could reduce about $4 \%$ the pes length (see $U$ in Fig. 4).

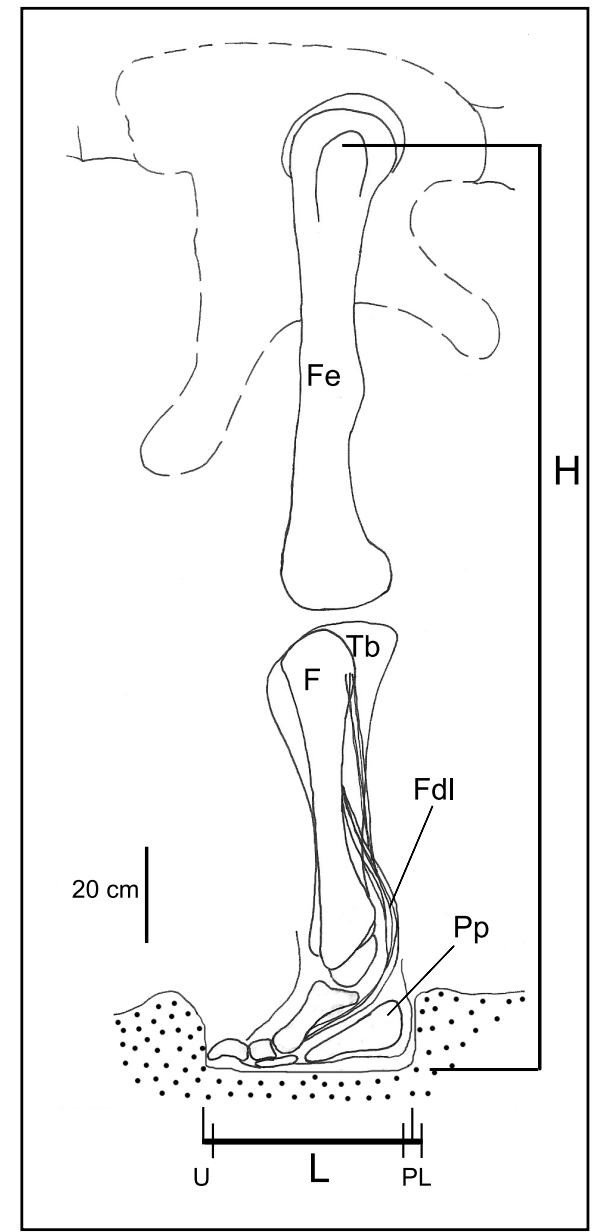

Fig. 4 - Reconstruction of the hind limb of the titanosaur MUCPv1533 (Neuquén, Argentina) and interpretation of a hypothetic pes track. Abbreviations: F, fibula; Fe, femur; Fdl, flexor digitorum longus muscle; H, height of hip joint; L, length of the pes track; PL, variation of the track length after different development of the plantar pad; Pp, plantar pad; $\mathrm{Tb}$, tibia.

\section{Estimation OF SPEEd AND Size}

Both graphic and numerical estimations (Fig. 4 and equation 2) of hind limb reconstruction for MUCPv1533 indicate a hip height $(H)$ of $197.2 \mathrm{~cm}$ and a pes track of $43 \mathrm{~cm}$ length (with a variation of $\pm 2 \mathrm{~cm}$ ).

This implied that $H / L=4.586$, where:

$$
H \text { is about } 4.586 L
$$

The relation (3) can be used to estimate speed in derived titanosaurs, such as the Titanopodus trackmakers, following the general equation of Alexander (equation 1). The results are shown in Table I. 


\section{TABLE I}

Estimated speeds of Titanopodus trackmakers (Agua del Choique track site, Mendoza, Argentina). Abbreviations: MPD, manus-pes distance (measured between the anterior margin of both manus and pes tracks); MLP, manus-pes length; $H$, height of the hip joint; $\mathrm{S} / \mathrm{H}$, stride length-hip height ratio.

\begin{tabular}{c|c|c|c|c|c|c|c}
\hline Trackways & $\begin{array}{c}\text { Pes track } \\
\text { length } \\
(\mathrm{cm})\end{array}$ & $\begin{array}{c}\text { MPD } \\
(\mathrm{cm})\end{array}$ & $\begin{array}{c}\text { MPL } \\
(\mathrm{cm})\end{array}$ & $\begin{array}{c}\mathrm{H} \\
(\mathrm{cm})\end{array}$ & $\begin{array}{c}\text { Ses stride } \\
(\mathrm{cm})\end{array}$ & $\begin{array}{c}\text { Estimated } \\
\text { speed }\end{array}$ & $\mathrm{S} / \mathrm{H}$ \\
\hline AC-1 & 46 & 80.4 & 123.6 & 210.9 & 235 & $\begin{array}{c}1.361 \mathrm{~m} / \mathrm{s} \\
4.901 \mathrm{~km} / \mathrm{h}\end{array}$ & 1.11 \\
\hline AC-4 & 50 & 102.9 & 148 & 229.3 & 245 & $\begin{array}{c}1.323 \mathrm{~m} / \mathrm{s} \\
4.765 \mathrm{~km} / \mathrm{h}\end{array}$ & 1.06 \\
\hline
\end{tabular}

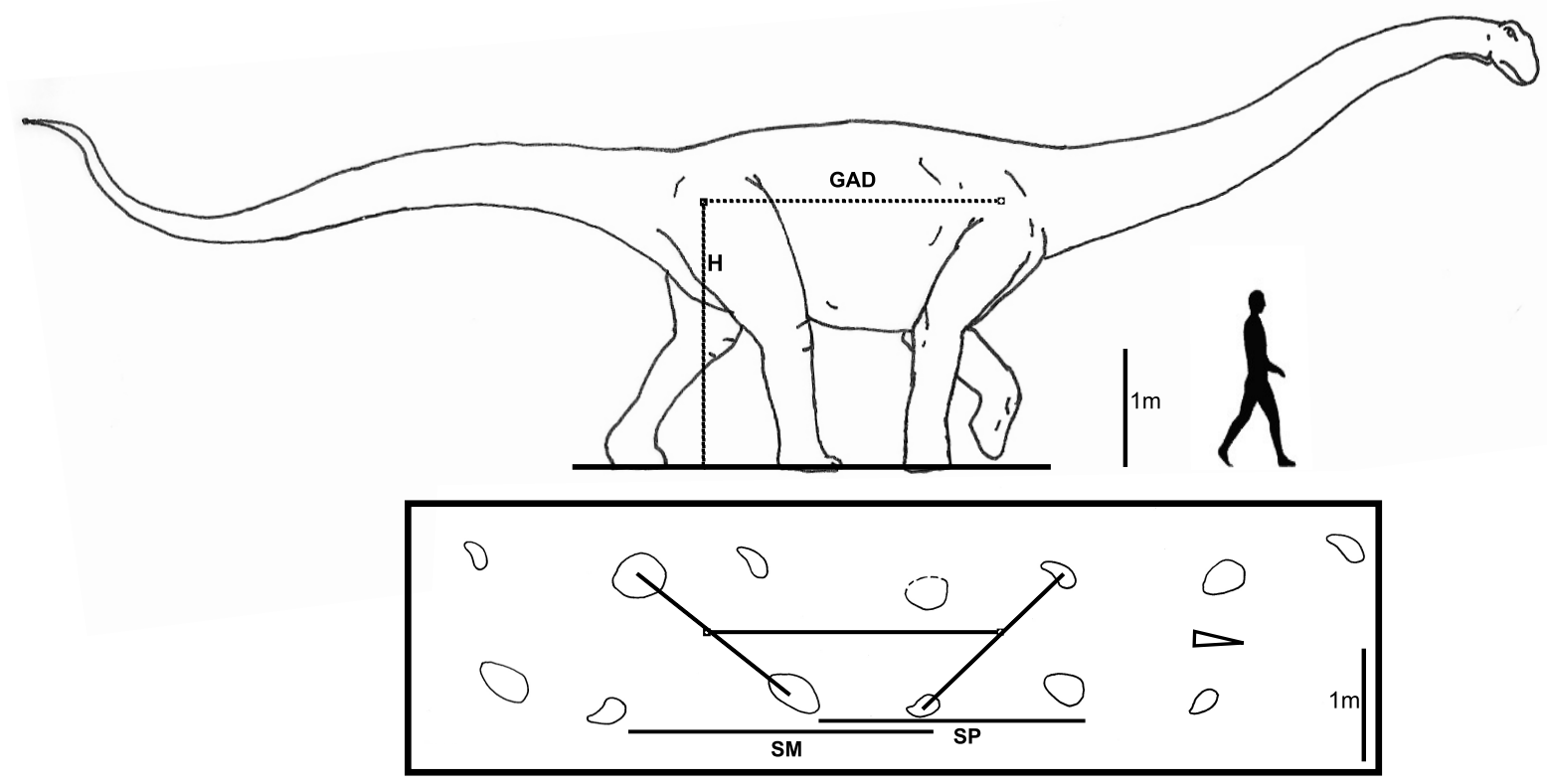

Fig. 5 - Size of Titanopodus trackmaker. Sketch of a derived titanosaur in scale with the Titanopodus footprints of the trackway AC-4. Abbreviations: GAD, gleno-acetabular distance; $\mathrm{H}$, height of hip joint; SM and SP, manus and pes stride, respectively.

According to this analysis, the Titanopodus tracks were produced by medium-sized titanosaurs. Sizes and anatomical proportions are estimated in based on the equation 3 and ichnological data. Trackways AC-1 and AC-4 were produced by sauropod specimens that had a hip height $(H)$ of $211 \mathrm{~cm}$ and $229 \mathrm{~cm}$, respectively (Fig. 5). The ratio of glenoacetabular distance to hip joint height $(G A D / H)$ is useful for estimating the body length and relative anatomical proportions. According to Mazzetta and Blanco (2001), the ratio $G A D / H$ of sauropods shows values that range from 0.97 to 1.26 , with an average of 1.09 .
In trackway AC-1 (18.5 m long; 27 ichnites), one titanosaurian individual walked at $4.90 \mathrm{~km} / \mathrm{h}$ towards the southwest (193-224 degrees). In trackway AC-4 (46.2 m long; 71 ichnites), a slightly larger titanosaur walked at $4.76 \mathrm{~km} / \mathrm{h}$ following a sinuous pathway towards the south (176 degrees), southwest (224 degrees), south (172 degrees) and, finally, again the southwest (253 degrees). The stride values ( $245 \mathrm{~cm}$ for the pes) and the pes length are larger than those from trackway AC-1 $(235 \mathrm{~cm})$, but they show a similar speed. In both trackways, some pes tracks reach a depth of 5-25 cm and exhibit a distorted contour. Some of them are elongated (about 50-60 cm 
length) in comparison with the best preserved prints that reach 46 and $50 \mathrm{~cm}$ in trackways $\mathrm{AC}-1$ and $\mathrm{AC}-4$, respectively. In elongated and distorted tracks, the presence of prominent rims indicates high water content in the substrate and some degree of sliding of the pedes during locomotion. Thus, the Titanopodus trackmakers moved at moderate speed, indicating their capacity to effectively walk over very saturated substrates. The ratio of stride length to hip height $(S / H)$ reaches values of 1.11 , indicating that the gait is a walk (not a trot or run), after the definitions of Alexander (1976) and Thulborn and Wade (1984).

The estimated speeds of sauropods generally never surpass $7.2 \mathrm{~km} / \mathrm{h}$ (Thulborn 1990). For example, the sauropod trackmakers of Rotundichnus muenchehagensis from the Lower Cretaceous of Germany show ranges from 3.1 to $4.5 \mathrm{~km} / \mathrm{h}$ (Lockley et al. 2004) (although these authors used the ratio $H=5 L$ to calculate the speed in these wide-gauge trackways). Another study of speed in a wide-gauge sauropod trackmaker was made using ichnites from the Candeleros Formation of northern Patagonia. In this unit, the Sauropodichnus trackmakers reached speeds of only 1.7-2.3 km/h (Mazzetta and Blanco 2001), indicating a very slow pace in a medium-sized basal titanosaur. In contrast, according to this analysis, the walking speeds of Titanopodus trackmakers $(4.9 \mathrm{~km} / \mathrm{h})$ are somewhat faster than those previously inferred for most sauropods.

\section{ACKNOWLEDGMENTS}

I thank Alexander Kellner (Brazil) for inviting me to publish in this volume, and J. Calvo (Argentina) for his comments and collaboration. Martin Lockley, Matthew Lamanna, Leonardo Salgado and two anonymous reviewers offered useful suggestions. I am also grateful to students and volunteers who have participated in the field work during years. Our work in dinosaur ichnology was supported by projects of CONICET (PIP 0713/09), Instituto de Ciencias Básicas and Universidad Nacional de Cuyo (2009-2011), and Agencia Nacional de Promoción Científica y Tecnológica (PICT 2005-33984). I also thank Instituto Argentino de Nivología, Glaciología y Ciencias Ambientales (Mendoza) for their important field support, and the Municipalidad de Malargüe for their collaboration.

\section{RESUMO}

Estimativas de velocidade a partir de trilhas de Titanopodus mendozensis González Riga e Calvo fornecem informações a respeito da locomoção de saurópodes titanossaurianos que viveram na América do Sul durante o Cretáceo Superior. Icnitos de Titanopodus foram encontrados em Agua del Choique, sendo este um sítio de pegadas recentemente descoberto na Formação Loncoche, Campaniano Superior-Maastrichiano Inferior de Mendonza, Argentina. Este estudo de velocidade segue a hipótese de similaridade dinâmica proposta por Alexander. Como um refinamento deste método, uma equação complementar é aqui apresentada tomando como base um espécime titanossauriano articulado coletado em estratos que são tidos como correlativos àqueles que forneceram as pegadas de Titanopodus (Formação Allen, Bacia Neuquén). Esta análise indica que a altura da bacia pode ser estimada como tendo 4,586 vezes o comprimento da pegada do pé em titanossauros derivados. A velocidade é calculada com uma estimativa da altura da bacia e as medidas da passada. O estudo de duas trilhas de medidas amplas indica que os icnitos de Titanopodus foram produzidos por titanossauros de tamanho mediano (altura da bacia de 211-229 cm) que caminhavam a 4,7-4,9 km/h em direção ao sul e sudeste, seguindo, em parte, um caminho sinuoso. Estas velocidades e algumas características tafonômicas das pegadas (margens proeminentes, formatos alongados distorcidos) apontam para a capacidade de titanossauros derivados de caminhar efetivamente sobre um substrato muito úmido e escorregadio. No registro icnológico, as velocidades de caminhada dos geradores de Titanopodus são um pouco mais rápidas do que aquelas previamente inferidas para a maioria dos saurópodes.

Palavras-chave: velocidade, Sauropoda, Titanopodus, Cretáceo, Argentina.

\section{REFERENCES}

AlEXANDER RM. 1976. Estimates of the speed of dinosaurs. Nature 261: 129-130.

ALEXANDER RM. 1991 Doubts and assumptions in dinosaur mechanics. Interdiscipl Sci Rev 16: 175-181.

Alexander RM. 2006. Dinosaur biomechanics. Proc R Soc 273: 1849-1855.

Alonso RN. 1980. Icnitas de dinosaurios (Ornithopoda: Hadrosauridae) en el Cretácico superior del norte de Argentina. Act Geol Lilloana 15: 55-63. 
AlONSO RN AND Marquillas R. 1986. Nueva localidad con huellas de dinosaurios y primer hallazgo de aves en la Formación Yacoraite (Maastrichthiano) del norte argentino. Actas IV Congr Arg de Paleont y Bioest 2: $33-42$.

Bonaparte JF AND Powell JE. 1980. A continental assemblage of tetrapods from the Upper Cretaceous beds of El Brete, northwestern Argentina (Sauropoda, Coelurosauria, Carnosauria, Aves). Mem Soc Geol Fran 139: 19-28.

BONNAN MF. 2003. The evolution of manus shape in sauropod dinosaurs: implications for functional morphology, forelimb orientation, and phylogeny. J Vert Paleont 23: 595-613.

BONNAN MF. 2005. Pes anatomy in sauropod dinosaurs: implications for functional morphology, evolution, and phylogeny. In: CARPENTER K AND TIDWELL V (Eds), Thunder-Lizards: The Sauropodomorph Dinosaurs. Indiana University Press, Bloomington, p. 346-380.

BorSUK-BIALYNICKA M. 1977. A new camarasaurid sauropod Opisthocoelicaudia skarzynskii, gen.n. sp.n. from the Upper Cretaceous of Mongolia. Palaeontol Pol 37: 45-64.

Calvo JO. 1991. Huellas de dinosaurios en la Formación Río Limay (Albiano-Cenomaniano?), Picún Leufú, Provincia del Neuquén, República Argentina (Ornithischia-Saurischia: Sauropoda-Theropoda). Ameghiniana 28: $241-258$.

CALvo JO. 1999. Dinosaurs and other vertebrates of the Ezequiel Ramos Mexía área, Neuquén-Patagonia Argentina. 13-15. In: TOMIDA Y, RICH T AND VICKERS-RICH P (Eds), Proceedings of the Second Gondwanan Dinosaur Symposium. National Science Museum Monographs 15, p. $13-15$.

Calvo JO And Mazzetta GV. 2004. Nuevos hallazgos de huellas de dinosaurios en la Formación candeleros (albiano-Cenomaniano), Picún leufú, Neuquén, Argentina. Ameghiniana 41: 545-554.

Calvo Jo, Porfiri JD, GonzÁlez Riga BJ and KellNER AWA. 2007. A new Cretaceous terrestrial ecosystem from Gondwana with the description of a new sauropod dinosaur. An Acad Bras Cienc 79: 529-541.

CAsamiquela RM and Fasola A. 1968. Sobre pisadas de dinosaurios del Cretácico Inferior de Colchagua (Chile). Departamento de Geología de la Universidad de Chile 30: 1-24.

CoOmBs WP. 1978. Theoretical aspects of cursorial adaptations in dinosaurs. Q Rev Biol 53: 393-418.
CURry Rogers K. 2009. The postcranial osteology of Rapetosaurus krausei (Sauropoda: Titanosauria) from the Late Cretaceous of Madagascar. J Vert Paleont 29(4): 1046-1086.

Curry Rogers K And Foster CA. 2001. The last of the dinosaur titans: a new sauropod from Madagascar. Nature 412: 530-534.

Farlow JO, Pittman JG AND HaWthorne JM. 1989. Brontopodus birdi, Lower Cretaceous sauropod footpints from the U.S. Gulf Coastal Plain. In: GilletTe DD AND LOCKLEY MG (Eds), Dinosaur Tracks and Traces. Cambridge University Press, Cambridge, p. 371-394.

GALLUP MR. 1989. Funstional morphology of the hind foot of the Texas sauropod Pleurocoelus sp. Indet. Geol Soc of Amer 238: 71-74.

GonZÁlez Riga BJ. 1999. Hallazgo de vertebrados fósiles en la Formación Loncoche, Cretácico Superior de la provincia de Mendoza, Argentina. Ameghiniana 36: 401410.

GonZÁlez Riga BJ. 2002. Estratigrafía y Dinosaurios del Cretácico Tardío en el extremo sur de la provincia de Mendoza, Argentina. PhD Dissertation, National University of Córdoba (Argentina), $280 \mathrm{p}$.

GonzÁlez Riga BJ and Calvo JO. 2007. Huellas de dinosaurios saurópodos en el Cretácico de Argentina. In: DíAZ-MARTíNEZ E AND RÁBANo I (Eds), $4^{\text {th }}$ European Meeting on the Palaeontology and Stratigraphy of Latin America, Cuadernos del Museo Geominero 8: 173-179.

GonzÁlez Riga BJ And CAlvo JO. 2009. A new widegauge Sauropod track site from the Late Cretaceous of Mendoza, Neuquén Basin, Argentina. Palaeontology 52(3): 631-640.

GonzÁlez Riga BJ, CAlvo JO And Porfiri J. 2007. A new articulated eutitanosaur from Northern Patagonia, Argentina. XX Congresso Brasileiro de Paleontología (Buzios, Brasil) Annais 17.

GonzÁlez Riga BJ, Calvo JO And Porfiri J. 2008. An articulated titanosaur from Patagonia (Argentina): new evidences of the pedal evolution. Palaeoworld 17: 33-40.

GonzÁlez Riga BJ ANd Parras AM. 1998. Paleoambiente y Paleontología de la Formación Loncoche (Cretácico Superior) en Ranquil-Có, sur de la provincia de Mendoza, Argentina. Actas del VII Congreso Argentino de Paleontología y bioestratigrafía 1: 81 .

HENDERSON DM. 2003. Footprints, trackways and hip heights of bipedal dinosaur-testing hip height predictions with computer models. Ichnos 10: 99-114.

LEONARDI G. 1989. Inventory and stastistics of the South American dinosaurian Ichnofauana and its Paleobiologi- 
cal interpretation. In: Gillette D AND LOCKLEY M (Eds), Dinosaur Tracks and Traces, Cambridge University Press, Cambridge, p. 165-178.

LOCKLEY MG. 1986. A guide to dinosaur tracksites of the Colorado Plateau and American Southwest. University of Colorado at Denver, Geology Department Magazine, Special Issue 1: 56.

Lockley MG. 1991. Tracking Dinosaurs: A New look at an Ancient World. Cambridge University Press, New York, $238 \mathrm{p}$.

LOCKLEY MG. 2007. The morphodynamics of dinosaurs, other archosaurs, and their trackways: holistic insights into relationships between feet, limb and the whole body. Soc Sediment Geol, Spec Publ 88: 27-51.

LOCKLEY MG AND JACKSON P. 2008. Morphodynamic perspectives on convergence between the feet and limb of sauropod and humans: two cases of hypermorphosis. Ichnos 15: 140-157.

Lockley MG, Shulp AS, Meyer, CA, Leonardi G And Kerumba Mamani D. 2002. Titanosaurid trackways from the Upper Cretaceous of Bolivia: evidence for large manus, wide-gauge locomotion and gregarious behavior. Cret Res 23: 383-400.

Lockley MG, WRight JL AND Thies D. 2004. Some observations on the dinosaur tracks at Münchehagen (Lowe Cretaceous), Germany. Ichnos 2: 261-274.

MARTinelli A AND Forasiepi AM. 2004. Late Cretaceous vertebrates from Bajo de Santa Rosa (Allen Formation), Río Negro province, Argentina, with the description of a new sauropod dinosaur (Titanosauridae). Rev Mus Argent Cienc Nat 6(2): 257-305.

MARTínez R, GimÉnEz O, RodríGuez J, LunA M AND LAMANNA M. 2004. An articulated specimen of the basal Titanosaurian (Dinosauria: Saurópoda) Epachthosaurus sciuttoi from the Early Late Cretaceous Bajo Barreal Formation of Chubut Province, Argentina. J Vert Paleont 24(1): 107-120.

Mazzetta GV and Blanco RE. 2001. Speeds of dinosaurs from the Albian-Cenomanian of Patagonia and sauropod stance and gait. Act Pal Polonica 46: 235-246.

Meyer CA, Hippler D And Lockley MG. 2001. The Late Cretaceous vertebrate ichnofacies of Bolivia - facts and implications. In: VII INTERNATIONAL SYMPOSIUM on Mesozoic Terrestrial Ecosystems. Asociación Paleontológica Argentina, Publicación Especial 7: 133-138.

Miller CE, Basu C, Fritsch G, Hildebrandt T and
HUTCHINSON JR. 2007. Ontogenetic scaling of foot musculoskeletal anatomy in elephants. JR Soc Interface 5: 465-475.

Moreno K AND Benton M. 2005. Occurrence of sauropod dinosaur tracks in the Upper Jurassic of Chile (redescription of Iguanodonichnus frenki). JS Am Earth Sci 20(3): 253-257.

Moreno K AND Benton M. 2005. Occurrence of sauropod dinosaur tracks in the Upper Jurassic of Chile (redescription of Iguanodonichnus frenki). JS Am Earth Sci 20(3): 253-257.

Moreno K, Blanco N And Tomlinson A. 2004. Nuevas huellas de dinosaurios del Jurásico Superior en el norte de Chile. Ameghiniana 41(4): 535-543.

Moreno K And Pino M. 2002. Huellas de dinosaurios (Theropoda-Ornitopoda-Sauropoda) de la Formación Baños del Flaco, VI Región, Chile: paleoambiente y paleoetología. Rev Geol Chile 29: 191-206.

Parras A, Casadío S AND Pires M. 1998. Secuencias depositacionales del Grupo Malargüe (límite CretácicoPaleógeno), sur de la provincia de Mendoza, Argentina. Publicación Especial de la Asociación Paleontológica Argentina 5: 181-192.

Powell JE. 1987. The Late Cretaceous Fauna from Los Alamitos, Patagonia, Argentina. Part. VI. The titanosaurids. Rev Mus Argent Cienc Nat 3(3): 147-153.

Previtera ME and GonzÁlez Riga BJ. 2008. Primer hallazgo de vertebrados fósiles en la Formación Loncoche (Cretácico Superior) en el área de Calmu-Co, Mendoza, Argentina. Ameghiniana 45: 349-359.

Romano M, Whyte M And JACKSOn SJ. 2007. Trackway Ratio: A New Look at Trackway Gauge in the Analysis of Quadrupedal Dinosaur Trackways and its Implications for Ichnotaxonomy. Ichnos 14: 257-270.

SAlgado L AND AzPilicueta C. 2000. Un nuevo saltasaurino (Sauropoda, Titanosauridae) de la provincia de Río Negro (Formación Allen, Cretácico Superior), Patagonia, Argentina. Ameghiniana 37: 259-264.

SAlgado L, CoRia RA AND CAlvo JO. 1997. Evolution of Titanosaurid Sauropods. I: Phylogenetic analysis based on the postcraneal evidence. Ameghiniana 34: 3-32.

SAntos VF dos, Lockley MG, Meyer CA, CARVAlho J, Galopim de CARvalho AM and Moratalla JJ. 1994. A new sauropod tracksite from the Middle Jurassic of Portugal. Gaia 10: 5-13.

Thulborn RA. 1982. Speeds and gaits of dinosaurs. Palaeogeogr Palaeoclimat Palaeoec 38: 227-256. 
ThUlborn RA. 1990. Dinosaur tracks. Chapman and Hall, London, $410 \mathrm{p}$.

THULBORn RA AND WADE M. 1984. Dinosaur trackways in the Winton formation (mid-Cretaceous) of Queensland. Mem Queensland Mus 21: 413-517.

UPCHURCH P. 1994. Manus claw function in sauropod dinosaurs. Gaia 10: 161-171.

WILSON JA. 2002. Sauropod dinosaur phylogeny: critique and cladistic analysis. Zool J Linn Soc 136: 217-276.
Wilson JA AND CARRANO MT. 1999. Titanosaurs and the origin of "wide gauge" trackways: a biomechanical and systematic perspective on sauropod locomotion. Paleobiology 25: 252-267.

Wilson JA AND SERENO P. 1998. Early Evolution and Higher-level Phylogeny of Sauropod Dinosaurs. J Vert Paleont 18(Suppl 2): 1-68.

WRIGHT JL. 2006. Steps in understanding sauropod biology. In: CURry Rogers KA AND WiLson JA (Eds), University of California Press, Berkeley, p. 252-284. 